\title{
Day Times Milligram per Milliliter
}

National Cancer Institute

\section{Source}

National Cancer Institute. Day Times Milligram per Milliliter. NCI Thesaurus. Code C85588.

Days times milligrams per milliliter. 